\title{
Sun Ginseng Protects Endothelial Progenitor Cells From Senescence Associated Apoptosis
}

\author{
Wooseok Im", Jin-Young Chung", Jaejun Bhan, Jiyeon Lim, Soon-Tae Lee, Kon Chu, Manho Kim* \\ Department of Neurology, Seoul National University Hospital, SNUMC, 101 Daehakro, Chongno-ku, Seoul, Korea, 110-744
}

Endothelial progenitor cells (EPC) are a population of cells that circulate in the blood stream. They play a role in angiogenesis and, therefore, can be prognostic markers of vascular repair. Ginsenoside $\operatorname{Rg}_{3}$ prevents endothelial cell apoptosis through the inhibition of the mitochondrial caspase pathway. It also affects estrogen activity, which reduces EPC senescence. Sun ginseng (SG), which is heat-processed ginseng, has a high content of ginsenosides. The purpose of this study was to investigate the protective effects of SG on senescence-associated apoptosis in EPCs. In order to isolate EPCs, mononuclear cells of human blood buffy coats were cultured and characterized by their uptake of acetylated low-density lipoprotein (acLDL) and their binding of Ulex europaeus agglutinin I (ulex-lectin). Flow cytometry with annexin-V staining was performed in order to assess early and late apoptosis. Senescence was determined by $\beta$-galactosidase ( $\beta$-gal) staining. Staining with 4'-6-Diamidino-2-phenylindole verified that most adherent cells $(93 \pm 2.7 \%)$ were acLDL-positive and ulex-lectin-positive. The percentage of $\beta$-gal-positive EPCs was decreased from $93.8 \pm 2.0 \%$ to $62.5 \pm 3.6 \%$ by SG treatment. A fluorescence-activated cell sorter (FACS) analysis showed that $4.9 \%$ of EPCs were late apoptotic in controls. Sun ginseng decreased the apoptotic cell population by $39 \%$ in the late stage of apoptosis from control baseline levels. In conclusion, these results show antisenescent and antiapoptotic effects of SG in human-derived EPCs, indicating that SG can enhance EPC-mediated repair mechanisms.

Key words: Panax ginseng, Apoptosis, Endothelial progenitor cells (EPCs), Aging, Sun ginseng

\section{INTRODUCTION}

Bone-marrow-derived endothelial progenitor cells (EPCs) play an integral role in the regulation and protection of the endothelium. EPCs from peripheral blood can also enhance angiogenesis when they are infused into host animals [1,2]. The number of EPCs can be used as a surrogate biologic marker of vascular function, and the number of EPCs is inversely correlated with the cumulative cardiovascular risk [3-7]. In addition, reduced numbers of EPCs in patients with cerebrovascular dysfunctions have been noted $[8,9]$, suggesting that the number of EPCs can be a biological marker in patients with migraine, ischemic strokes, cerebral large artery atheroscle-

(cc) This is an Open Access article distributed under the terms of the Creative Commons Attribution Non-Commercial License (http://creativecommons.org/licenses/by-nc/3.0/) which permits unrestricted non-commercial use, distribution, and reproduction in any medium, provided the original work is properly cited. rosis, and even in Alzheimer's disease (AD) [8].

Sun ginseng (SG), which is processed at $120^{\circ} \mathrm{C}$, results in an increased production of ginsenoside $\mathrm{Rg}_{3}, \mathrm{Rg}_{5}$, and $\mathrm{Rk}_{1}$. This processed ginseng includes ingredients, such as ginsenoside $\mathrm{Rk}_{2}, \mathrm{Rk}_{3}, \mathrm{Rs}_{4}, \mathrm{Rs}_{5}, \mathrm{Rs}_{6}$, and $\mathrm{Rs}_{7}[10-$ 13]. These ginsenosides protect endothelial cells (ECs) from apoptosis through the inhibition of mitochondrial caspase. ECs undergo apoptosis and exhibit increased levels of caspase- 9 and caspase- 3 activities and DNA fragmentation after $24 \mathrm{~h}$ of serum deprivation. However, caspase- 9 and caspase-3 levels were suppressed by the addition of $(20 \mathrm{~S}) \mathrm{Rg}_{3}$. (20S) $\mathrm{Rg}_{3}$ prevents $\mathrm{EC}$ apoptosis

Received 25 May. 2011, Revised 03 Aug. 2011, Accepted 03 Aug. 2011

"These authors contributed equally to this work.

"Corresponding author

E-mail: kimmanho@snu.ac.kr

Tel: +82-2-2072-2193, Fax: +82-2-3672-7553 
through the Akt-dependent inhibition of the mitochondrial apoptotic signaling pathway [14]. A dysfunction of ECs or apoptosis has been proposed to be an underlying mechanism in neurodegenerative disorders. For example, in $\mathrm{AD}$ dementia, the decreased clearing of $\beta$-amyloid deposits can contribute to the pathogenesis of this disorder $[15,16]$.

In this study, we investigated the antisenescent and antiapoptotic activities of SG on EPCs, which may be potentially related to $\mathrm{EC}$ function in degenerative disorders, as well as in vascular repair.

\section{MATERIALS AND METHODS}

\section{Materials}

SG (Ginseng Science Inc., Seoul, Korea), endothelial basal medium (EBM-2, Clonetics Corporation, San Diego, CA, USA), EGM-2-MV-SingleQuots (Clonetics Corporation), fetal bovine serum (FBS, GIBCO, Invitrogen Corporation, Burlingame, CA, USA), FITC-labeled Ulex europaeus agglutinin I (ulex-lectin, Sigma-Aldrich Co., St. Louis, MO, USA), DiI-labeled acetylated lowdensity lipoprotein (acLDL; Invitrogen Corporation) [17], Annexin V-FITC (BD Biosciences, San Jose, CA, USA), and Propidium iodide (PI, Sigma-Aldrich Co.) were used in this study.

\section{Isolation and Characterization of EPCs}

Human EPCs were cultured as previously described $[18,19]$. Briefly, EPCs were obtained by isolating mononuclear cells using a Ficoll density-gradient centrifugation of human blood buffy coats. Cells were resuspended in EBM-2 that was supplemented with EGM-2-MV-SingleQuots containing vascular endothelial growth factor, basic fibroblast growth factor, insulin-like growth factor- 1 , epidermal growth factor, and 5\% FBS. A total of 1 $\times 10^{6}$ mononuclear cells $/ \mathrm{cm}^{2}$ was plated onto fibronectincoated tissue culture flasks. After $4 \mathrm{~d}$ of culture, nonadherent cells were discarded by washing with PBS. In order to confirm the EPC phenotypes, adherent cells were incubated with DiI-labeled acLDL for $1 \mathrm{~h}$. After fixation, they were incubated with FITC-labeled ulex-lectin for $1 \mathrm{~h}$. Cells were visualized with an inverted fluorescent microscope, and adherent cells that stained positive for both FITC-ulex-lectin and DiI-acLDL were determined to be EPCs. Blood samples were acquired with donors' consent, and the experimental procedures were approved by the institutional review board of Seoul National University Hospital.

\section{Experimental protocol and treatment with SG}

In order to determine the apoptotic and antiapoptotic effects of SG, a flow cytometric analysis was performed. Flow cytometry was performed on EPCs treated with vehicle or SG. In brief, EPCs were seeded onto a 6-well plate at a concentration of $1 \times 10^{5}$, cultured for 4 days, and then treated with SG $(200 \mu \mathrm{g} / \mathrm{mL})[20,21]$ after removal of the supernatant since there was the most effective at a dose of $200 \mu \mathrm{g} / \mathrm{mL} \mathrm{SG}$ (data not shown). In $24 \mathrm{~h}$, EPCs were stained with Annexin-V and PI after the detachment of cells with $0.25 \%$ trypsin-EDTA (Invitrogen Corporation).

A $\beta$-galactosidase ( $\beta$-gal) assay was done in order to test for antiaging effects after the isolation of EPCs [22]. EPCs were plated on coverslips coated with poly-Llysine and cultured for 4 days. Cells were resuspended in media supplemented with SG and cultured for $24 \mathrm{~h}$. The number of $\beta$-gal-stained cells (blue structures) was counted in 4 fields. The area of a field was magnified at $100 \mathrm{X}$ by an inverted microscope (BX61, Olympus Corporation, Tokyo, Japan).

\section{Flow cytometric analysis}

To analyze the patterns of apoptosis in EPCs after treatment with SG, a flow cytometric analysis was performed with cells after labeling with Annexin-V-FITC and PI. Adherent cells were collected, washed, and resuspended in cold binding buffer (PBS [pH 7.4], $140 \mathrm{mM}$ $\mathrm{NaCl}$, and $2.5 \mathrm{mM} \mathrm{CaCl}_{2}$ ) and diluted to a final concentration of $5 \times 10^{5}$ cells $/ \mathrm{mL}$. Aliquots of $1 \times 10^{5}$ cells were incubated with $0.5 \mu \mathrm{L}$ of Annexin-V-FITC and $10 \mu \mathrm{L}$ of PI per tube. After $15 \mathrm{~min}$ at room temperature, $400 \mu \mathrm{L}$ of binding buffer was added before the flow cytometric analysis. For each sample, $1 \times 10^{4}$ cells were analyzed on a FACS II flow cytometer (BD Biosciences). CellQuest ${ }^{\mathrm{TM}}$ Pro software (BD Biosciences) was used to perform the flow cytometric analysis.

\section{Flow Cytometric Analysis of Annexin-V in EPCs}

Annexin- $\mathrm{V}$ staining indicates the stages of cell death resulting from either apoptotic or necrotic processes. Cells in early apoptosis are Annexin-V-positive and PInegative, and cells that are in late apoptosis or are already dead are both Annexin-V- and PI-positive.

\section{Cytochemical detection of $\beta$-gal staining}

The monolayers of cells were washed 2 times with PBS and then fixed with $2 \%$ formaldehyde and $0.2 \%$ glutaraldehyde for $5 \mathrm{~min}$. Staining solution was added [1 mg/mL 5-bromo-4-chloro-3-inolyl- $\beta$-D-galactosidase 
A

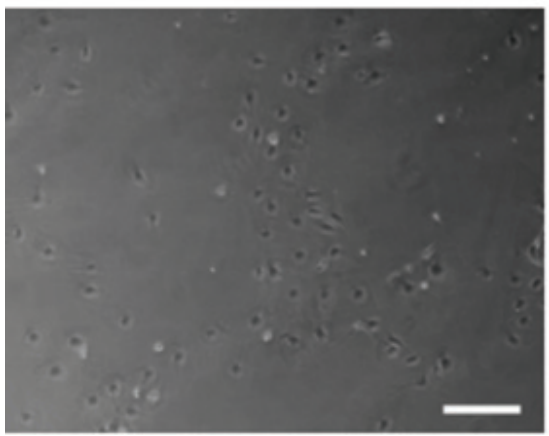

B

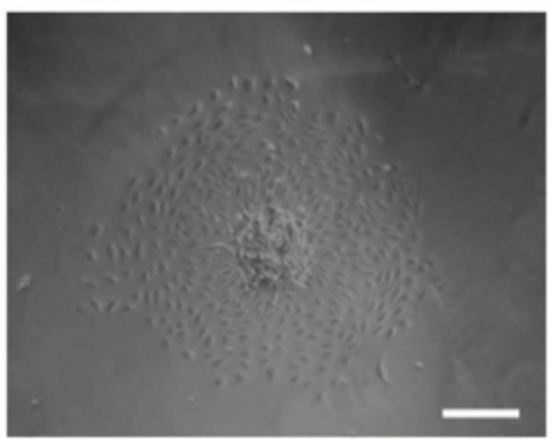

Fig. 1. Endothelial progenitor cell culture. Peripheral Blood Mononuclear Cells at day 2 (A). A central core of rounded cells that are surrounded by elongated and spindle-shaped cells appears after 7 days in culture conditions. They are defined and counted as Colony-Forming Units (B). Bar=100 $\mu \mathrm{m}$.

A

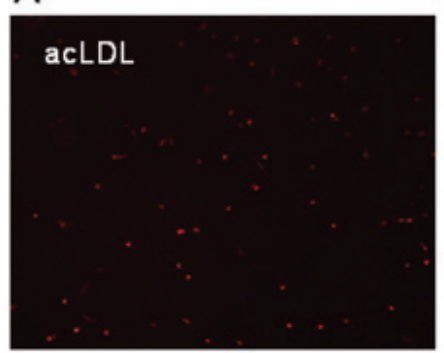

C

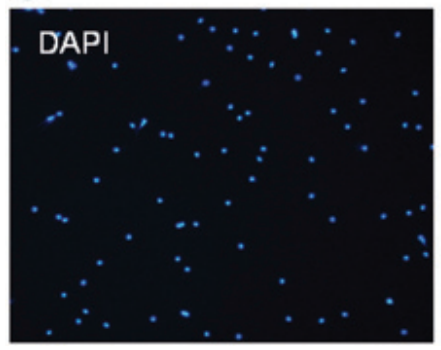

B

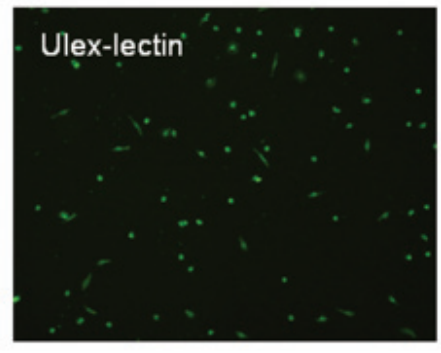

D

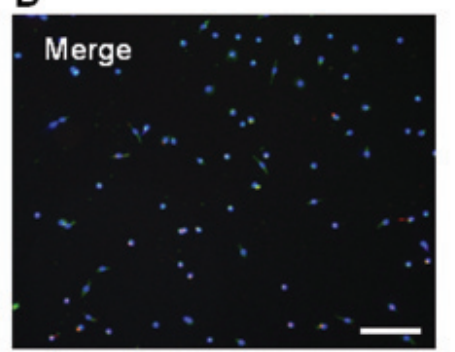

E

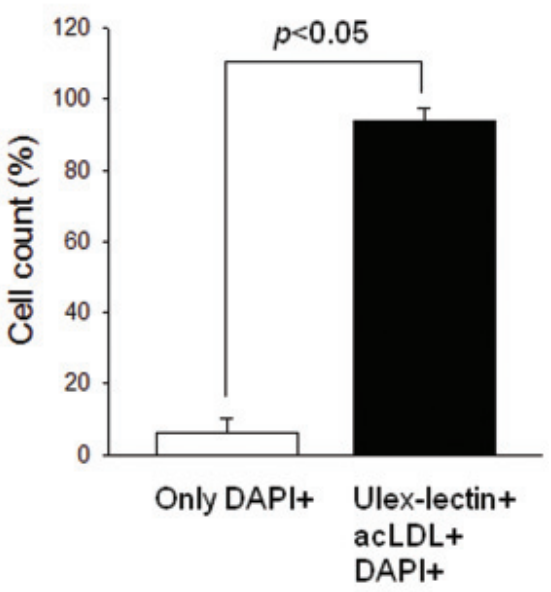

Fig. 2. Endothelial progenitor cell characterization (EPCs). Adherent cells are positive for the uptake of acetylated low-density lipoprotein (acLDL, A) and the binding of FITC-Ulex europaeus agglutinin I (ulex-lectin, B). EPCs stained with the nuclear stain DAPI (C) show that all nuclei are found in cells that are acLDL-positive and bind ulex-lectin (D). There is $93 \pm 2.7 \%$ of ulex-lectin and acLDL-positive cells in total cells $(E)(p<0.05)$. Bar=100 $\mu \mathrm{m}$.

(X-gal) in dimethylformamide, $40 \mathrm{mM}$ citric acid/sodium phosphate, $\mathrm{pH} 6.0,5 \mathrm{mM}$ potassium ferrocyanide, $5 \mathrm{mM}$ potassium ferricyanide, $150 \mathrm{mM} \mathrm{NaCl}$, and $2 \mathrm{mM}$ $\mathrm{MgCl}_{2}$ ], and the cells were incubated at $37^{\circ} \mathrm{C}$ for $18 \mathrm{~h}$. After incubation, the cells were washed 2 times with PBS.

\section{Data analysis}

All values are expressed as mean \pm standard deviation. The analysis was conducted using repeated measures of analysis of variance and an unpaired Student's $t$-test. A 2-tailed $p$-value less than 0.05 was considered to be significant.

\section{RESULTS}

\section{Culture and characterization of endothelial pro- genitor cells}

On day 2, cultured peripheral blood mononuclear cells (PBMCs) were scattered on the culture plate, and on day 7 , the cells showed the colony-forming units (CFU) or outgrowth cells (Fig. 1). In previous study, the EPC-CFU numbers were developed to $72.4 \pm 24.5$ when $1 \times 10^{4}$ EPCs derived from normal person were cultured in 12 wellplate [21,23]. The EPCs exhibited a common endothelial phenotype that was defined by the uptake of acLDL and 
the binding of ulex-lectin [4,6,24]. In order to confirm the phenotypes of PBMCs cultured with EGM2MV, we subcultured CFU cells and stained them with acLDL and ulex-lectin. Fig. 2 shows that the subcultured CFU cells were positive for acLDL and showed ulex-lectin binding. The staining of nuclei with DAPI verified that most adherent cells (93 $\pm 2.7 \%$ ) were acLDL-positive and ulexlectin-positive.

\section{Senescence-associated $\beta$-gal staining in endothe- lial progenitor cells and effect of sun ginseng}

In order to investigate the anti-senescent effect of SG, we compared the differences in $\beta$-gal-positive cell number between EPCs treated with SG $(200 \mu \mathrm{g} / \mathrm{mL})$ or vehicle for $24 \mathrm{~h}$. The mean number of senescence-associated (SA)- $\beta$-gal-stained cells treated with SG was $62.5 \pm 3.6 \%$, whereas that in controls was $93.8 \pm 2 \%$. Compared with vehicle, SG resulted in a significant diminution of the proportion of SA-stained cells $(p<0.001$, Fig. 3B).

\section{The antiapoptotic eff ects of sun ginseng on endo- thelial progenitor cells}

A flow cytometric analysis of Annexin-V-positive cells was performed in order to investigate the antiapoptotic effects of SG in EPCs. In control conditions, $4.9 \%$ of cells were undergoing late apoptotic cell death. EPCs treated with SG for $24 \mathrm{~h}$ had lower percentages of late apoptotic cells, with $3.0 \%$ in the late stage of apoptosis. Therefore, the population of apoptotic cells was reduced by SG compared to controls, which had 39\% in late apoptosis $(p<0.05)$ (Fig. 4).

\section{DISCUSSION}

In this study, we attempted to test the antisenescent and antiapoptotic effects of SG on EPCs. The number of SA- $\beta$-gal staining-positive EPCs was lower after SG treatment than that with vehicle. Moreover, apoptotic cells were decreased in SG-treated EPCs compared to controls. Based on our data, SG appears to have effects on EPCs that involve both antisenescent and antiapoptotic mechanisms.

Recent studies have shown that degenerating neuronal cells display characteristics of apoptosis $[25,26]$. Intrahippocampal injections of amyloid $\beta$ peptide $(\mathrm{A} \beta)$ induced a spatial memory deficit, apoptosis, and caspase- 9 activation in hippocampal neurons [27]. Interference with or alterations of the Akt signaling pathway can be a feature in several neurodegenerative diseases that are characterized by neuronal attrition [28-30]. Therefore, reagents that suppress neuronal apoptosis have been developed as therapeutic agents in several neurodegenerative disorders [31,32]. Panax ginseng has been reported to have an antiapoptotic effect in both in vivo and in vitro experiments [33]. In this experiment, SG lowered the number of Annexin-V-positive EPCs in a flow cytometric analysis $[34,35]$, supporting the previous findings that $\mathrm{Rb}_{3}$ inhibited apoptosis [10-12].

SG, which removes peroxide from the human body, has been reported to have strong antioxidant activities compared to the current ginsengs. SG also has effects on fatigue relief, antiaging, and improvements of circulation $[21,36] . \mathrm{Rg}_{3}$ in SG affects estrogen activity that reduces

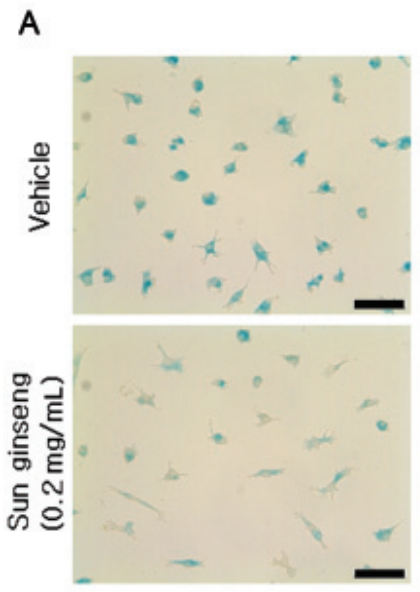

B

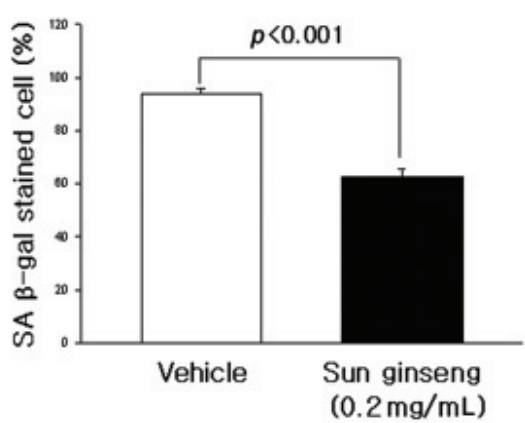

Fig. 3. Senescence-associated (SA) $\beta$-galactosidase ( $\beta$-gal) staining in endothelial progenitor cell (EPCs) after treatment with Sun ginseng Cytochemically detectable $\beta$-gal staining at $\mathrm{pH} 6.0$ was conducted as a marker of cellular senescence. Sun gineng-treated EPCs exhibit a lower level of SA $\beta$-gal staining than that of vehicle-treated controls $(p<0.05)$. 
A

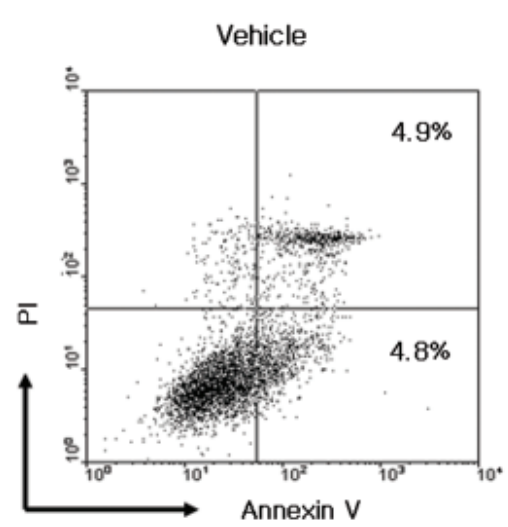

B

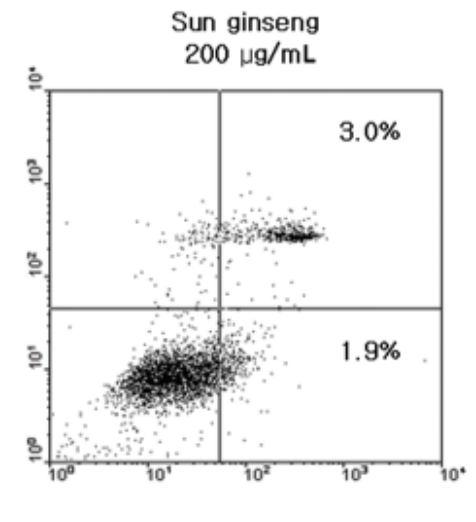

Fig. 4. Flow Cytometric Analysis of Annexin-V in EPCs. The lower and right box in the figure shows the early apoptotic population (PI-negative, Annexin-V-positive), whereas the upper and right box shows the late apoptotic population (PI-positive, Annexin-V-positive). The percentage of late apoptotic cells is $4.9 \%$ in $A$ and $3.0 \%$ in $B$.

EPC senescence through the augmentation of telomerase activity [37]. Therefore, it can be plausible that SG has effects on slowing senescence in EPCs, as shown with SA- $\beta$-gal staining [38-40]. In this study, we confirmed that SA $\beta$-gal staining in EPCs was decreased when compared to that of vehicle controls, indicating that SG has antisenescent effects on EPCs.

Dementia is one of the most common human disorders associated with aging. $\mathrm{AD}$, which is the most frequent type of dementia, exhibits degenerating neuronal loss in the brain $[41,42]$. Amyloid plaques in the extracellular space are known to be the main mediator of the pathogenesis of $\mathrm{AD}[43,44]$. Circulating angiogenic cells (CACs), such as EPCs, have been shown to have functions in the clearance of amyloid $\beta$ peptide $(\mathrm{A} \beta)[45,46]$. Therefore, endothelial senescence in $\mathrm{AD}$ is attributable to the faulty clearance of $\mathrm{A} \beta$, which accelerates the progression of disease $[47,48]$. CACs participate in the maintenance of the endothelium by replacing dysfunctional ECs or by releasing angiogenic growth factors $[49,50]$. Recently, dysfunctions of EPCs have been proposed to be a cause of $\mathrm{AD}$ [9]. In addition, efficacies of treatment with Korean red or Panax ginseng in patients with $\mathrm{AD}$ have been reported [51], warranting a correlation study of ginsenosides, EPCs, and AD.

In conclusion, SG reduced the senescence and apoptosis in EPCs. Given that EPCs constitute a circulating pool of cells and augment neovascularization by integrating into newly developing capillaries $[3,52,53]$, we suggest that SG can be an effective treatment for vascular repair and for disorders associated with the function and number of EPCs [3-7,23,54].

\section{ACKNOWLEDGEMENTS}

This work was supported by Ginseng science inc., the Korea Health 21 R\&D Project(A092058) and WCU Neurocytomics.

\section{REFERENCES}

1. Iwaguro, H., Yamaguchi, J., Kalka, C., Murasawa, S., Masuda, H., Hayashi, S., Silver, M., Li, T., Isner, J. M. and Asahara, T., Endothelial progenitor cell vascular endothelial growth factor gene transfer for vascular regeneration, Circulation 2002;105:732-738.

2. Assmus, B., Schachinger, V., Teupe, C., Britten, M., Lehmann, R., Dobert, N., Grunwald, F., Aicher, A., Urbich, C., Martin, H., Hoelzer, D., Dimmeler, S. and Zeiher, A. M., Transplantation of Progenitor Cells and Regeneration Enhancement in Acute Myocardial Infarction (TOPCARE-AMI), Circulation 2002;106:3009-3017.

3. Hill, J. M., Zalos, G., Halcox, J. P., Schenke, W. H., Waclawiw, M. A., Quyyumi, A. A. and Finkel, T., Circulating endothelial progenitor cells, vascular function, and cardiovascular risk, N Engl J Med 2003;348:593-600.

4. Vasa, M., Fichtlscherer, S., Aicher, A., Adler, K., Urbich, C., Martin, H., Zeiher, A. M. and Dimmeler, S., Number and migratory activity of circulating endothelial progenitor cells inversely correlate with risk factors for coronary artery disease, Circ Res 2001;89:E1-7.

5. Schatteman, G. C., Hanlon, H. D., Jiao, C., Dodds, S. G. and Christy, B. A., Blood-derived angioblasts accelerate blood-flow restoration in diabetic mice, $\mathrm{J}$ Clin Invest 2000;106:571-578. 
6. Tepper, O. M., Galiano, R. D., Capla, J. M., Kalka, C., Gagne, P. J., Jacobowitz, G. R., Levine, J. P. and Gurtner, G. C., Human endothelial progenitor cells from type II diabetics exhibit impaired proliferation, adhesion, and incorporation into vascular structures, Circulation 2002;106:2781-2786.

7. Fadini, G. P., Miorin, M., Facco, M., Bonamico, S., Baesso, I., Grego, F., Menegolo, M., de Kreutzenberg, S. V., Tiengo, A., Agostini, C. and Avogaro, A., Circulating endothelial progenitor cells are reduced in peripheral vascular complications of type 2 diabetes mellitus, J Am Coll Cardiol 2005;45:1449-1457.

8. Lee, S. T., Chu, K., Jung, K. H., Park, H. K., Kim, D. H., Bahn, J. J., Kim, J. H., Oh, M. J., Lee, S. K., Kim, M. and Roh, J. K., Reduced circulating angiogenic cells in Alzheimer disease, Neurology 2009;72:1858-1863.

9. Lee, S. T., Chu, K., Jung, K. H., Jeon, D., Bahn, J. J., Kim, J. H., Kun Lee, S., Kim, M. and Roh, J. K., Dysfunctional characteristics of circulating angiogenic cells in Alzheimer's disease, J Alzheimers Dis 2010;19:12311240 .

10. Lee, K. Y., Lee, Y. H., Kim, S. I., Park, J. H. and Lee, S. K., Ginsenoside-Rg5 suppresses cyclin E-dependent protein kinase activity via up-regulating p21Cip/WAF1 and down-regulating cyclin E in SK-HEP-1 cells, Anticancer Res 1997;17:1067-1072.

11. Liu, W. K., Xu, S. X. and Che, C. T., Anti-proliferative effect of ginseng saponins on human prostate cancer cell line, Life Sci 2000;67:1297-1306.

12. Xu, T. M., Xin, Y., Cui, M. H., Jiang, X. and Gu, L. P., Inhibitory effect of ginsenoside $\operatorname{Rg} 3$ combined with cyclophosphamide on growth and angiogenesis of ovarian cancer, Chin Med J (Engl) 2007;120:584-588.

13. Yoo, J. H., Kwon, H. C., Kim, Y. J., Park, J. H. and Yang, H. O., KG-135, enriched with selected ginsenosides, inhibits the proliferation of human prostate cancer cells in culture and inhibits xenograft growth in athymic mice, Cancer Lett;289:99-110.

14. Kiseljakovic, E., Jadric, R., Hasic, S., Ljuboja, L., Radovanovic, J., Kulenovic, H. and Winterhalter-Jadric, M., Mitochondrial medicine - a key to solve pathophysiology of xxi century diseases, Bosn J Basic Med Sci 2002;2:4648.

15. Bredesen, D. E., Rao, R. V. and Mehlen, P., Cell death in the nervous system, Nature 2006;443:796-802.

16. Zhao, B., Natural antioxidants protect neurons in Alzheimer's disease and Parkinson's disease, Neurochem Res 2009;34:630-638.

17. Rehman, J., Li, J., Orschell, C. M. and March, K. L., Peripheral blood "endothelial progenitor cells" are derived from monocyte/macrophages and secrete angiogenic growth factors, Circulation 2003;107:1164-1169.

18. Hur, J., Yoon, C. H., Kim, H. S., Choi, J. H., Kang, H. J., Hwang, K. K., Oh, B. H., Lee, M. M. and Park, Y. B., Characterization of two types of endothelial progenitor cells and their different contributions to neovasculogenesis, Arterioscler Thromb Vasc Biol 2004;24:288-293.

19. Yoon, C. H., Hur, J., Park, K. W., Kim, J. H., Lee, C. S., Oh, I. Y., Kim, T. Y., Cho, H. J., Kang, H. J., Chae, I. H., Yang, H. K., Oh, B. H., Park, Y. B. and Kim, H. S., Synergistic neovascularization by mixed transplantation of early endothelial progenitor cells and late outgrowth endothelial cells: the role of angiogenic cytokines and matrix metalloproteinases, Circulation 2005;112:16181627.

20. Peralta, E. A., Murphy, L. L., Minnis, J., Louis, S. and Dunnington, G. L., American Ginseng inhibits induced COX-2 and NFKB activation in breast cancer cells, $\mathrm{J}$ Surg Res 2009;157:261-267.

21. Keum, Y. S., Park, K. K., Lee, J. M., Chun, K. S., Park, J. H., Lee, S. K., Kwon, H. and Surh, Y. J., Antioxidant and anti-tumor promoting activities of the methanol extract of heat-processed ginseng, Cancer Lett 2000;150:41-48.

22. Severino, J., Allen, R. G., Balin, S., Balin, A. and Cristofalo, V. J., Is beta-galactosidase staining a marker of senescence in vitro and in vivo?, Exp Cell Res 2000;257:162-171.

23. Chu, K., Jung, K. H., Lee, S. T., Park, H. K., Sinn, D. I., Kim, J. M., Kim, D. H., Kim, J. H., Kim, S. J., Song, E. C., Kim, M., Lee, S. K. and Roh, J. K., Circulating endothelial progenitor cells as a new marker of endothelial dysfunction or repair in acute stroke, Stroke 2008;39:14411447.

24. Kalka, C., Masuda, H., Takahashi, T., Kalka-Moll, W. M., Silver, M., Kearney, M., Li, T., Isner, J. M. and Asahara, $\mathrm{T}$., Transplantation of ex vivo expanded endothelial progenitor cells for therapeutic neovascularization, Proc Natl Acad Sci U S A 2000;97:3422-3427.

25. Majd, S., Zarifkar, A., Rastegar, K. and Takhshid, M. A., Different fibrillar Abeta 1-42 concentrations induce adult hippocampal neurons to reenter various phases of the cell cycle, Brain Res 2008;1218:224-229.

26. Abdul, H. M., Calabrese, V., Calvani, M. and Butterfield, D. A., Acetyl-L-carnitine-induced up-regulation of heat shock proteins protects cortical neurons against amyloidbeta peptide 1-42-mediated oxidative stress and neurotoxicity: implications for Alzheimer's disease, J Neurosci Res 2006;84:398-408.

27. Li, J., Wang, G., Liu, J., Zhou, L., Dong, M., Wang, R., Li, X., Li, X., Lin, C. and Niu, Y., Puerarin attenuates 
amyloid-beta-induced cognitive impairment through suppression of apoptosis in rat hippocampus in vivo, Eur $\mathrm{J}$ Pharmacol;649:195-201.

28. Nakagami, Y., Inhibitors beta-amyloid-induced toxicity by modulating the Akt signaling pathway, Drug News Perspect 2004; 17:655-660.

29. Burke, R. E., Inhibition of mitogen-activated protein kinase and stimulation of Akt kinase signaling pathways: Two approaches with therapeutic potential in the treatment of neurodegenerative disease, Pharmacol Ther 2007;114:261-277.

30. Junyent, F., Alvira, D., Yeste-Velasco, M., de la Torre, A. V., Beas-Zarate, C., Sureda, F. X., Folch, J., Pallas, M., Camins, A. and Verdaguer, E., Prosurvival role of JAK/ STAT and Akt signaling pathways in MPP+-induced apoptosis in neurons, Neurochem Int;57:774-782.

31. Mattson, M. P., Neuronal life-and-death signaling, apoptosis, and neurodegenerative disorders, Antioxid Redox Signal 2006;8:1997-2006.

32. Mattson, M. P., Apoptosis in neurodegenerative disorders, Nat Rev Mol Cell Biol 2000;1:120-129.

33. Zhang, G., Liu, A., Zhou, Y., San, X., Jin, T. and Jin, Y., Panax ginseng ginsenoside-Rg2 protects memory impairment via anti-apoptosis in a rat model with vascular dementia, J Ethnopharmacol 2008;115:441-448.

34. Koopman, G., Reutelingsperger, C. P., Kuijten, G. A., Keehnen, R. M., Pals, S. T. and van Oers, M. H., Annexin $\mathrm{V}$ for flow cytometric detection of phosphatidylserine expression on B cells undergoing apoptosis, Blood 1994;84:1415-1420.

35. Vermes, I., Haanen, C., Steffens-Nakken, H. and Reutelingsperger, C., A novel assay for apoptosis. Flow cytometric detection of phosphatidylserine expression on early apoptotic cells using fluorescein labelled Annexin V, J Immunol Methods 1995;184:39-51.

36. Kim, W. Y., Kim, J. M., Han, S. B., Lee, S. K., Kim, N. D., Park, M. K., Kim, C. K. and Park, J. H., Steaming of ginseng at high temperature enhances biological activity, J Nat Prod 2000;63:1702-1704.

37. Imanishi, T., Hano, T. and Nishio, I., Estrogen reduces endothelial progenitor cell senescence through augmentation of telomerase activity, J Hypertens 2005;23:16991706.

38. Dimri, G. P., Lee, X., Basile, G., Acosta, M., Scott, G., Roskelley, C., Medrano, E. E., Linskens, M., Rubelj, I., Pereira-Smith, O. and et al., A biomarker that identifies senescent human cells in culture and in aging skin in vivo, Proc Natl Acad Sci U S A 1995;92:9363-9367.

39. Gire, V. and Wynford-Thomas, D., Reinitiation of DNA synthesis and cell division in senescent human fibroblasts by microinjection of anti-p53 antibodies, Mol Cell Biol 1998;18:1611-1621.

40. Serrano, M., Lin, A. W., McCurrach, M. E., Beach, D. and Lowe, S. W., Oncogenic ras provokes premature cell senescence associated with accumulation of p53 and p16INK4a, Cell 1997;88:593-602.

41. Ryu, S. Y., Kwon, M. J., Lee, S. B., Yang, D. W., Kim, T. W., Song, I. U., Yang, P. S., Kim, H. J. and Lee, A. Y., Measurement of precuneal and hippocampal volumes using magnetic resonance volumetry in Alzheimer's disease, J Clin Neurol 2010;6:196-203.

42. Lim, T. S., Iaria, G. and Moon, S. Y., Topographical disorientation in mild cognitive impairment: a voxel-based morphometry study, J Clin Neurol 2010;6:204-211.

43. Glabe, C., Intracellular mechanisms of amyloid accumulation and pathogenesis in Alzheimer's disease, J Mol Neurosci 2001;17:137-145.

44. Fiala, J. C., Mechanisms of amyloid plaque pathogenesis, Acta Neuropathol 2007;114:551-571.

45. Brenner, S. R., Roh, J. K., Lee, S. T., Chu, K., Jung, K. H., Lee, S. K. and Kim, M., Reduced circulating angiogenic cells in Alzheimer disease, Neurology;74:346; author reply 346-347.

46. Lee, S. T., Chu, K., Jung, K. H., Jeon, D., Bahn, J. J., Kim, J. H., Kun Lee, S., Kim, M. and Roh, J. K., Dysfunctional characteristics of circulating angiogenic cells in Alzheimer's disease, J Alzheimers Dis;19:1231-1240.

47. Donnini, S., Solito, R., Cetti, E., Corti, F., Giachetti, A., Carra, S., Beltrame, M., Cotelli, F. and Ziche, M., Abeta peptides accelerate the senescence of endothelial cells in vitro and in vivo, impairing angiogenesis, Faseb $\mathrm{J} ; 24: 2385-2395$.

48. Minamino, T., Miyauchi, H., Yoshida, T., Tateno, K., Kunieda, T. and Komuro, I., Vascular cell senescence and vascular aging, J Mol Cell Cardiol 2004;36:175-183.

49. Zlokovic, B. V., Neurovascular mechanisms of Alzheimer's neurodegeneration, Trends Neurosci 2005;28:202208.

50. Urbich, C. and Dimmeler, S., Endothelial progenitor cells: characterization and role in vascular biology, Circ Res 2004;95:343-353.

51. Heo, J. H., Lee, S. T., Chu, K., Oh, M. J., Park, H. J., Shim, J. Y. and Kim, M., An open-label trial of Korean red ginseng as an adjuvant treatment for cognitive impairment in patients with Alzheimer's disease, Eur J Neurol 2008; 15:865-868.

52. Kinnaird, T., Stabile, E., Burnett, M. S., Lee, C. W., Barr, S., Fuchs, S. and Epstein, S. E., Marrow-derived stromal cells express genes encoding a broad spectrum of arteriogenic cytokines and promote in vitro and in vivo 
arteriogenesis through paracrine mechanisms, Circ Res 2004;94:678-685.

53. Nagata, T., Kai, H., Shibata, R., Koga, M., Yoshimura, A. and Imaizumi, T., Oncostatin M, an interleukin-6 family cytokine, upregulates matrix metalloproteinase- 9 through the mitogen-activated protein kinase kinase-extracellular signal-regulated kinase pathway in cultured smooth mus- cle cells, Arterioscler Thromb Vasc Biol 2003;23:588593.

54. Ghani, U., Shuaib, A., Salam, A., Nasir, A., Shuaib, U., Jeerakathil, T., Sher, F., O’Rourke, F., Nasser, A. M., Schwindt, B. and Todd, K., Endothelial progenitor cells during cerebrovascular disease, Stroke 2005;36:151-153. 